\title{
Introduction: The medium, the message, and media geography in the 21 st century
}

\author{
John C. Finn · Joseph Palis
}

Published online: 11 June 2015

(C) Springer Science+Business Media Dordrecht 2015

\section{The medium and the message}

The summer of 2014 witnessed a seemingly endless series of massive global events: the epidemic spread of Ebola through West Africa; the rise of ISIS and its declaration of a worldwide caliphate; the continuing simmer of tensions between Russia and Ukraine; the kidnapping of nearly 300 Nigerian school girls by Boko Haram; an immigration crisis along the U.S.Mexico border as tens of thousands of undocumented and unaccompanied minor children arrived seeking refuge in the U.S.; a(nother) lopsided war in Gaza as the Israeli Defense Forces bombarded that densely populated $5 \times 25$-mile strip of desert along the Mediterranean Sea; a record-breaking drought in California, symptomatic of a changing global climate and a sign that humanity could be getting dangerously close to an environmental point of no return. This is, by no means, an exhaustive list.

In our digital age of the 24-hour news cycle, it should come as no surprise that the media (broadly defined) played, and continues to play, an important role in shaping

J. C. Finn ( $\square)$

Christopher Newport University, Newport News, VA, USA

e-mail: john.finn@cnu.edu

\section{J. Palis}

University of the Philippines-Diliman, Quezon City, Philippines

e-mail: josephpalis@gmail.com our individual and collective understanding of these events. Or, it might be more accurate to say, the media has played an outsized role in shaping our fundamental misunderstanding of them. To play on McLuhan's muchquoted (and often misinterpreted) quip: the medium is still the message (McLuhan 1964). And while McLuhan's influential tome is a much broader foray into the philosophy and theory of the development of human communication, there is something about this pithy quote that still resonates when applied more narrowly to the $21 \mathrm{st}$ century digital media environment in which we find ourselves today. In a 1960 interview with the Canadian Broadcasting Corporation, McLuhan stated:

The world is now like a continually sounding tribal drum where everybody gets the message all of the time [...] A princess gets married in England and boom, boom, boom go the drums. We all hear about it. An earthquake in North Africa, a Hollywood star gets drunk-away go the drums again (CBC 1960).

That is, as Paul Hiebert (2014: np) wrote on the 50th anniversary of the publication of McLuhan's opus, "the content of the message isn't what matters; what matters is the medium, because it is the medium that modifies our senses when processing the received information." Or, as McLuhan elaborated in a 1969 interview with Playboy, this new media "context" is invisible to us, which makes it all the more powerful in shaping the messages received: 
I call this peculiar form of self-hypnosis Narcissus narcosis, a syndrome whereby man remains as unaware of the psychic and social effects of his new technology as a fish of the water it swims in. As a result, precisely at the point where a new media-induced environment becomes all pervasive and transmogrifies our sensory balance, it also becomes invisible (quoted in Hiebert 2014: np).

And while we hesitate to take this kind of "media determinism" to the degree that McLuhan did-Guy Debord famously accused McLuhan of being an "apologist" of the spectacle and "the most convinced imbecile of the century" (Debord 1983: 57; in MacDonald 2006: 505)—what is perfectly clear to us is that in this emergent age of digital media, the omnipresence of (increasingly digital) media, and the content that it delivers, has a radical impact on our individual and collective geographical understanding of the world that we inhabit.

\section{Ebola in the news}

Let us return to the case of the Ebola outbreak in West Africa that peaked in the late summer and fall of 2014. The timeline and trajectory of the outbreak is fairly straightforward. This strain of the virus first appeared in late 2013 in a remote village in southern Guinea, likely passed to humans from fruit bats being eaten as bush meat. The disease continued to spread in the region for several months before it was recognized as Ebola (Baize et al. 2014). By the time the virus had been identified in March 2014, it had spread to Liberia, infected a total of over 100 people in both countries, and killed nearly 70 . From there the outbreak spread rapidly, growing by hundreds and then thousands of cases per month across Guinea, Liberia, and Sierra Leone. By the time of this writing in April 2015, the World Health Organization estimates that there have been a total of over 25,500 cases and over 10,500 deaths in these three countries from this outbreak of the virus (WHO 2015), and these numbers are likely underreported by more than a factor of two (Meltzer et al. 2014).

While the overwhelming majority of cases and deaths of Ebola were in Guinea, Liberia, and Sierra Leone, the virus did spread beyond these borders. In late July the first case of Ebola was identified in Nigeria, setting off a chain of infections that led to at least 20 cases and eight deaths in that country (WHO 2015). By October the virus had spread to Mali, where there have been eight known cases and six deaths, and Senegal, where there was a single non-fatal case (WHO 2015). There have additionally been at least 24 cases of Ebola treated off the continent of Africa. Many were aid or healthcare workers who were diagnosed in West Africa and returned to Europe or the United States for treatment, though there were four diagnoses of Ebola inside of the United States. Of all 24 cases of Ebola treated outside of Africa, two patients died in the United States, two more in Spain, and one in Germany. The other 19 have recovered.

Even while governmental agencies and non-governmental organizations began sounding early alarms as the disease spread throughout West Africa, there was a consistent and significant lag between events unfolding on the ground in West Africa on the one hand, and media interest and thus public interest and political action in the U.S. on the other. ${ }^{1}$ Perhaps this is not surprising; in the mental maps of most Americans, the continent of Africa is already a largely a void, populated more by our fears, prejudices, and biases than by any geographically and historically accurate sense of this place. Wars rage, diseases spread, economies grow at break-neck speeds, governments collapse, and others display surprising durability, and barely a blip appears in the American mediascape. But once Ebola hit Dallas, and a week later New York City, the news media revved up, Americans started Googling, and the Twittersphere erupted. The problem, of course, is that the hysteria in the news media, especially on cable TV news, and the resulting public (mis)understanding of Ebola had very little to do with the facts on the ground.

A telling event occurred during the domestic hour of the Friday News Round-Up on the NPR and WAMU radio call-in program The Diane Rehm Show on October 17, 2014, many months into the epidemic in West Africa, but just 10 days after the death of Thomas Eric Duncan in a Dallas hospital, the first of

\footnotetext{
"McLuhan spoke of the "tribal drum" sounding and everyone getting the message all of the time. And indeed, the media has the ability to amplify stories in real time all over the world to millions, even, billions of viewers. But they have to choose to do so.
} 
two Ebola deaths in the United States. A caller to the show criticized the media coverage of Ebola in the U.S. by saying: "I think that the media coverage of the Ebola [sic] has been extremely excessive. I challenge the media to not mention the word Ebola for 1-hour" (Diane Rehm Show 2014: np). Responding to this criticism, Lisa Leher of Bloomberg News responded:

Whether the wall-to-wall coverage about the three infected people here in the U.S. is legitimate, you know, is a good question but look, people are interested in this. People are concerned... Two weeks ago the polling said that something like two-thirds of people weren't worried about Ebola. It's completely flipped. The most recent poll in the Washington Post this week said that 66, 67 percent of people were concerned about them or someone in their family getting Ebola. So, I mean, people are worried about it and they want information (Diane Rehm Show 2014, np).

The problem, though, is that multiple media studies in the wake of the Ebola outbreak in West Africa and its minimal spread to Europe and the United States have shown that the causative direction is precisely the opposite: rather than public interest driving media coverage, hysteria in the media leads to public concern.

Consider first the sheer volume of media coverage. As alluded to above, media coverage of Ebola, especially on cable television news, ${ }^{2}$ correlates tightly to the arrival of the virus in the United States, and especially the first cases diagnosed in the United States. Though Ebola had already been ravaging three

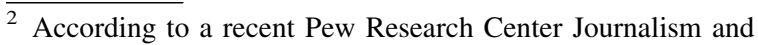
Media study, "while the largest audiences tune into local and network broadcast news, it is national cable news that commands the most attention from its viewers... While $38 \%$ of adults watch some cable news during the month, cable viewers-particularly the most engaged viewers-spend far more time with that platform than broadcast viewers do with local or network news... On average, the cable news audience devotes twice as much time to that news source as local and network news viewers spend on those platforms. And the heaviest cable users are far more immersed in that coveragewatching for more than an hour a day-than the most loyal viewers of broadcast television news. Even those adults who are the heaviest viewers of local and network news spend more time watching cable than those broadcast outlets" (Olmstead et al. 2013: np).
}

West African countries for several months, infecting tens of thousands and killing thousands, a single diagnosis of Ebola in the United States completely reshaped the domestic media landscape. But it's not simply the volume of coverage, but also the content. As many media critics have pointed out over the last several months, the content of the coverage has bordered on the absurd, from the suggestion that ISIS could send terrorists to West Africa to get Ebola and then transport it to the United States, to the invitation of ophthalmologist and fiction writer Robin Cook, best known for his 1987 novel Outbreak in which there is a deadly outbreak of Ebola in the United States, as an invited guest on CNN where he was introduced as "THE MAN WHO WROTE THE BOOK ON EBOLA" (Sandmeyer 2014, np) (Fig. 1). The volume, the speed, the breathlessness of the media coverage of Ebola in the United States, together with the oftentimes absurdity of the content of that coverage, has played a dramatic role in not only shaping Americans' (mis)conceptions of the threat of Ebola in the United States, but also their broader geographical understanding of what was, and continues to be, an overtly spatial issue. The results range from the comical to the deadly.

First, people throughout the United States thought that they were in danger on contracting the virus. The irony, of course, is that while it was incredibly unlikely that anyone in the U.S. would become infected with Ebola without visiting the affected countries in West Africa, half of Americans do not get a flue shot in any given year even though the flu kills nearly 50,000 people annually in the U.S. (Szabo 2014). According to Paul Offit, chief of infectious diseases at Children's Hospital of Philadelphia:

I bet that if we put out an Ebola virus vaccine tomorrow, half of this country would take it, even though it hasn't killed anyone who hasn't traveled [to the affected countries...] Yet you can't get parents to give their children an HPV vaccine to prevent a virus that kills 4000 U.S. citizens a year (quoted in Szabo 2014, np).

Second, reacting to both media hype and the resulting public hysteria, politicians and other public officials jumped into gear. Against the recommendations of the CDC, the WHO, and other medical experts, the Governors of New York and New Jersey put in place strict 21-day quarantines of anyone returning form the affected areas in West Africa and 


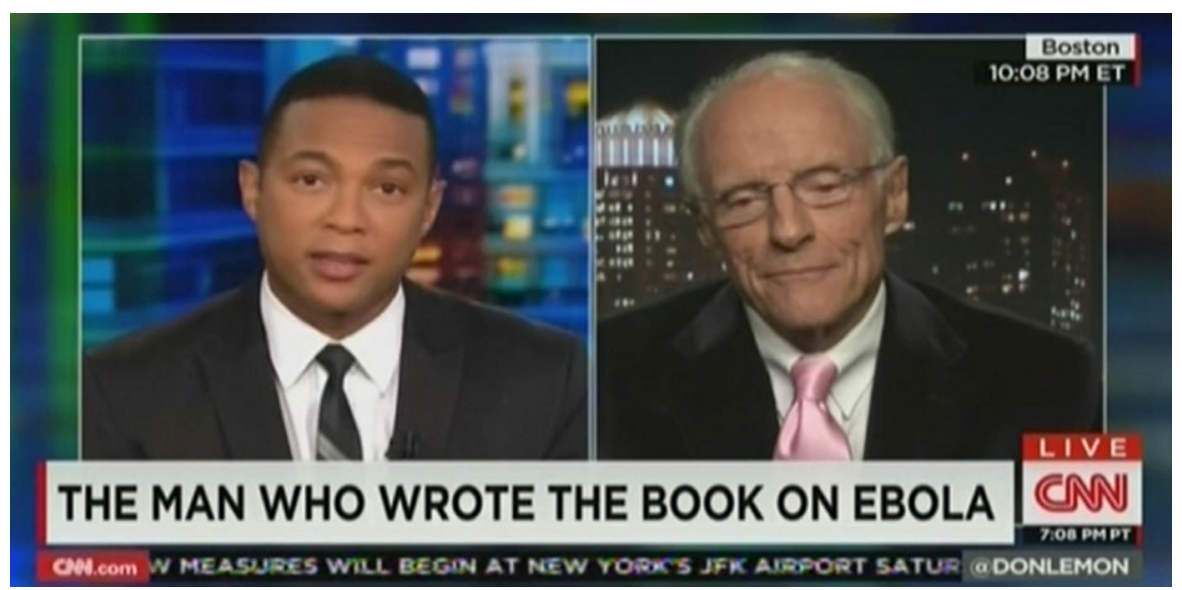

Fig. 1 CNN host Don Lemon interviews writer Robin Cook, author of the 1987 novel Outbreak

who was working with Ebola patients (Santora 2014). Politicians-Democrats and Republicans alikecalled for travel bans for anyone coming from the affected countries, while others called for the cancellation of all flights and a complete travel ban to and from those countries (e.g. Ferris 2014; Nelson 2014). One Texas college began rejecting admission to Nigerian applicants, stating that the college "is not accepting international students from countries with confirmed Ebola cases" (Jaschik 2014). (It didn't take long for someone on Twitter to point out that by October, when these letters began going out, Nigeria had zero cases of Ebola, while Texas had two.) And multiple schools in both Texas and Ohio closed for several days out of "an abundance of caution" (Szabo 2014: np) when news broke that the nurse who was infected with Ebola in a Dallas hospital had travelled by plane to Ohio. She was not symptomatic, and thus not infectious, at the time of her travel.

The irony - and danger - of this twisted geographical understanding is that it actually puts us allEuropeans, North Americans, and especially West Africans-at more risk rather than less. Mandatory three-week quarantines for medical personnel returning from West Africa lead directly to fewer medical personnel being willing to volunteer and work in West Africa. Similarly, flight cancellations and travel bans directly result in fewer supplies reaching the affected countries. In both cases, this slows down the response effort and facilitates the continued spread of the disease in West Africa, and potentially the arrival of new cases outside of that region.
In the end, perhaps a single New Jersey poll captures the depressing irony in all of this: in early October 2014, just after Liberian Eric Duncan was diagnosed with Ebola in Dallas, a poll of New Jersey residents found not only that a significant majority feared an outbreak of Ebola in the United States, but also that those who were following the story most closely in the media were the most misinformed, more likely to believe that an effective medicine existed and more likely to believe that the disease is easily spread (Boehlert 2014: np).

\section{Ebola in song}

It's important to remember, though, that the "media" in media geography is much broader than simply the news media. Music is another medium that has played an important role in shaping our geographical understanding of the 2014 Ebola outbreak. And this power of music is not unique to this particular crisis. In the West there is a long tradition of using the star power of music celebrities, and performances by those artists, to raise funds during, and in the aftermath of humanitarian crises. In this crisis, one song in particular has received significant attention, as much for the money it has raised as the criticism it has received. The song, Do They Know It's Christmas?, was originally written by Irish rocker Bob Geldof and Scottish singer-songwriter Midge Ure and recorded by the "supergroup" Band Aid in 1984 as a fundraiser for victims of the Ethiopian famine. After two more subsequent releases 
in 1989 (to raise money for the ongoing humanitarian crisis in Ethiopia) and 2004 (to raise money for the crisis in Darfur), Geldof and Ure teamed up yet again for the 30th anniversary of the original release to rerecord the song to raise money, this time for the Ebola crisis in West Africa. Participants included Bono, Sinéad O'Connor, One Direction, Seal, Chris Martin (of Coldplay), and Sam Smith, among many others. The lyrics were changed slightly from the original version to better fit Ebola, and the audio recording and music video were produced in a 36-hour period in November 2014. The song was release on Simon Cowell's British music competition show The $X$ Factor the next day, and the single went straight to the top of British music charts, selling over 300,000 copies and raising over $\$ 1.5$ million in its first week (Daheley and Crookes 2014; Suddath 2014). As of this writing the video has received over 9.8 million YouTube views.

This brief history of Do They Know It's Christmas?, however, doesn't even start to get at how the song simultaneously represents our collective mental map of Africa as an Orientalized dark continent, and how it plays an active role in perpetuating this view of "those" people in that mythical place "Africa." From the very first frames of the music video, a clear racialized and spatialized us/them binary is set up: a sick African woman in need of saving is juxtaposed with the British and Irish pop stars, nearly all of whom are white, who have gathered in the bright lights of the paparazzi to come together to perform this song and music video to save her (see Fig. 2).

As the music starts and the musicians slide from their limos and stride into the recording studio it becomes immediately apparent that this is essentially the same song that was released in 1984, 1989, and 2004. Africa is once again the same monolithic Other in need of saving by Western celebrities and clichés. It was only in this most recent version of the song that the lyrics were changed at all, and even then only slightly. The song opens, as it did in all previous versions, with musicians trading lines:

It's Christmas time, there's no need to be afraid (One Direction)

At Christmas time, we let in light and we banish shade (Ed Sheeran)

And in our world of plenty we can spread a smile of joy (Rita Ora)
Throw your arms around the world at Christmas time (Sam Smith)

But say a prayer and pray for the other ones (Paloma Faith)

At Christmas time it's hard but while you're having fun (Emeli Sandé)

There's a world outside your window and it's a world of dread and fear (Guy Garvey)

It's only at this point that the original lyric"Where the only water flowing/Is the bitter sting of tears"- has been changed to the more Ebolaappropriate "Where a kiss of love can kill you/ Where there's death in every tear." Just a line or two later the original lyric- "Well, tonight thank God it's them instead of you"- - has been changed to (the only slightly less offensive) "Well, tonight we're reaching out and touching you." (Does it even need to be pointed out that literally two lines after singing about how a kiss of love can kill and how there's death in every tear, the overwhelmingly white faces of Band Aid 30 are offering their saving "touch"?)

While a line-by-line analysis is beyond our scope, suffice here to say that the new version of the song, like all previous versions, serves to simultaneously reflect and reinforce our overwhelming geographical misunderstanding of this continent in all its diversity and complexity. As many critics have pointed out (e.g. Bady 2014; Taylor 2014), it might help to have the basic facts right before attempting to "save" Africa with a song. The title of the song, for instance, is baffling. Yes, "they" probably do know it's Christmas in "Africa," even with Ebola. And anyway, they very well might not care: a majority of the population of both Sierra Leone and Guinea are Muslim (the same can be said about the 2004 release of the song for the crisis in Darfur, a majority Muslim region). Further, in the original version dedicated to the famine in Ethiopia, lines like "Where nothing ever grows/no rain or rivers flow" fundamentally misunderstand the social production of famine (cf. Watts 1983; Sen 1999; Bady 2014). Ebola in West Africa is equally socially produced. As Bady (2014: np) points out: "in countries where the infrastructure exists to maintain public health, the outbreak has been short-lived. In Nigeria and Senegal, for example, the outbreak has been stopped in its tracks." The high mortality rate of the virus is equally socially produced. According to Paul 

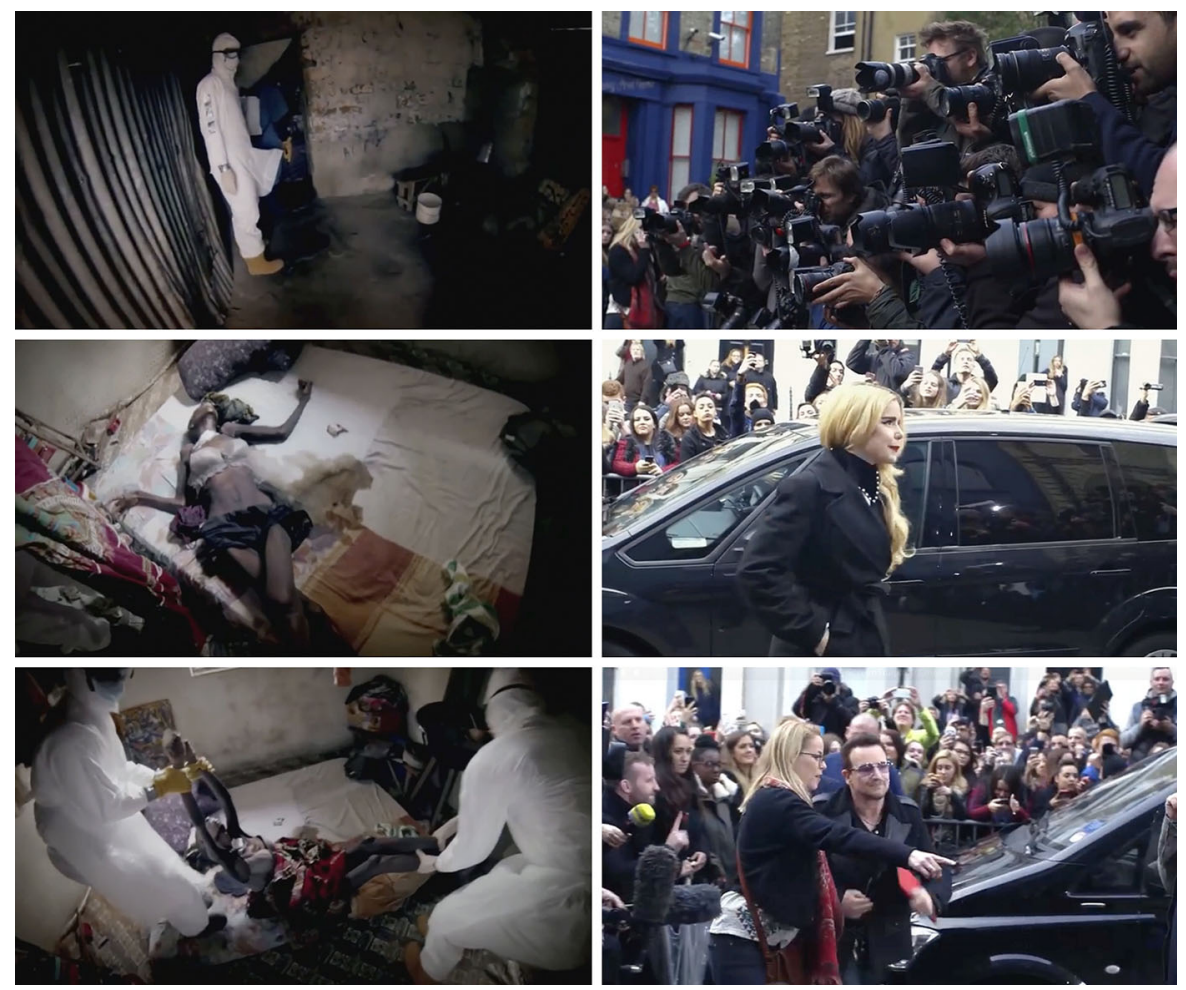

Fig. 2 Screen shots from the opening sequences from the music video for Band Aid 30: Do They Know It's Christmas?

Farmer, an infectious disease physician and Harvard global health professor:

[T]he fact is that weak health systems, not unprecedented virulence or a previously unknown mode of transmission, are to blame for Ebola's rapid spread. Weak health systems are also to blame for the high case-fatality rates in the current pandemic...An Ebola diagnosis need not be a death sentence. Here's my assertion as an infectious disease specialist: if patients are promptly diagnosed and receive aggressive supportive care-including fluid resuscitation, electrolyte replacement and blood products-the great majority, as many as 90 per cent, should survive (Farmer 2014: np).

To wit, 19 of the 24 (nearly $80 \%$ ) individuals treated for Ebola in Europe and North America survived.

Beyond reflecting a skewed, Orientalized view of "Africa," what's the harm of this song? After all, as many of its defenders have pointed out, it did raise over $\$ 1.5$ million for the cause. One critic sarcastically asked "how much have you raised for
Ebola?" (Parker 2014: np). But the very premise of that question misunderstands the power of the medium to broadly contribute to our geographical imaginations and thus frame and even shape our future actions-beyond downloading a song and contributing a buck to the cause. Ebola has been so deadly and has been able to spread so rapidly in these West African countries as a result of decades, even centuries of economic underdevelopment. When this crisis is over, when Geldof and Ure and Bono and One Direction go home, and when we stop downloading the song for the cause, the underlying social, political, and economic conditions will persist. In 2013 an estimated 584,000 people died of Malaria worldwide, $90 \%$ of them in Africa. There is no reason to think that 2015 will be any different. The song turns Ebola into a spectacle, focusing our collective attention on a rare, visually gruesome virus that we could have a hand in eradicating simply by downloading an $\mathrm{mp} 3$, while shielding from our view the much broader social, economic, and geographical realities, within which we are directly or indirectly implicated, that underlie 
this outbreak in the first place. In the words of Aaron Bady:

If we in the West just wanted to save lives, we would send doctors. Or better yet, we would train and support Liberian medical professionals. We would build infrastructure, not awareness. But that's much too simple, too obvious and not nearly glamorous enough. Especially since songs like "Do They Know It's Christmas?" encourage us to look for simple morality tales and barely updated Victorian fables about white men taking up the burden of saving Africa. They teach us to want infantile carols that flatter the imagination of consumers who like to pretend that purchasing a song or going to a concert can painlessly make poverty history. Even Jesus was more realistic about the persistence of poverty; the idea that a few songs can solve world hunger expresses a greater messianism than even the Messiah's-but apparently not greater than Bono's and Geldof's (Bady 2014: np).

In the final minutes of the music video, the artists come together to sing the final refrain. The camera pans over the overwhelming white group of faces as they sing "Heal the world, let them know it's Christmas time again." The musicians smile, embrace one another, and dance as they sing this ode to the Great White Hope. As the song ends and the screen fades to black, the credits roll:

The entire project is non-profit and all profits will go to the Band Aid trust in the global fight against Ebola

All partners involved have given their time and services for free to be a part of history

The track was recorded and the video made all within 36 hours

In the end, whether the news media or pop music, or the inevitable television series and movies already likely in the pipeline, our geographical consciousness is, at all times and in all places, shaped both by the content of mediated messages and the mediums through which we receive them. Understanding and analyzing our place in the world demands a serious engagement with multiple intersecting and oftentimes contradictory geographies of the media through which we experience, shape, and are shaped by the world.

\section{Introduction to the papers in this issue}

To that end, the papers in this special issue engage in a wide array of scholarly investigations on various forms of media in their varied permutations and afterlives. The authors deploy a variety of theoretical approaches to unpack a complex web of relations involving music, radio and audio drama, journalism, cinema, and the cyberworld. In uncovering the hidden and non-obvious relationalities, the papers presented in this special issue enhance and make legible visual, aural, and affective palimpsests to engage in a new(er) dialogue at the nexus of media, message, space, and place.

To begin with, three articles focus on the spatiality of sound and music, via public radio broadcasts of community news, via audio dramas and audio tours, and via various digital music formats. Based on a case study of community radio in Ocracoke, North Carolina, Brian Pompeii focuses on the still-understudied use of public radio broadcasts as a modality and tool for qualitative geographic research. The paper engages with audio media as a counter-discourse to the visual and textual repositories of data that qualitative researchers usually draw from. Calling radio broadcast a sonic space that "became a place of coming together for people and information," Pompeii emphasizes the efficacy of radio broadcasts in transforming the imagined space inhabited by live speech and utterances into a concrete space akin to a sonic sculpture.

Similarly, Torsten Wissman and Stefan Zimmermann seek to re-center discussions of the borderless space inhabited by sound as aiding in the cognitive creation of place. Using the examples of two different types of narrated audio-The Three Investigators (a German audio drama) and Austin Walking Tours (an audio-guided city tour of Austin in Texas) - the authors argue that sound acts as a storyteller that assists in shaping the listeners' formation of place. In the case of the audio-guided tour for the city of Austin, the storyteller not only describes particular places to the listeners by creating a "consistent (but slightly altered) image of the world," but also aids and encourages consumerism within the intricate patchwork of the city.

Adopting the concept of pastpresent to find common grounds between authenticity and mediated performance, Katrinka Somdahl-Sands and John Finn challenge the spatio-temporal dialectic through the 
non-representational performances of classical dance, street improvisations, and popular music as glimpsed in film, the internet, and digital music. Drawing from the theorizations of Walter Benjamin and Katie King, the authors provide examples that argue for the rethinking of authenticity in performances mediated by technology and the ever-shifting landscapes of spectatorship and public consumption.

While sound and performance lie outside the fixed dimensions of representation, a highly visual medium like film has been studied especially in the politics of content and form, and of scopic regimes and political economy. Two articles in particular in this issue not only challenge the dominant and popular readings of two films that are considered canons in the literature of cinema, but they also propose new understandings offered by the film's texts. David Clarke revisits Fritz Lang's cinematic city in Metropolis by employing Levi-Strauss' account of myth—specifically the myth of Percival in Wagner's Parsifal - to re-frame the film from its Oedipal trappings. Long associated with, among other popular textual film analyses, the incipient becoming of a National Socialist future, Clarke's Metropolis not only looks at modernity and the dichotomized relations between nature and culture, of the imaginary and symbolic, but also reflects on a possibility of an anti-Oedipal reading.

Kevin McHugh proposes a haptic dimension of cinema through Vittorio de Sica's Umberto $D$. by drawing from a phenomenological approach that implicates affect beyond the form of the representational articulations of cinema. Bringing Benjamin once again into the conversation through aura, as well as Giorgio Agamben's gestural cinema, McHugh proposes a haptic cinema that goes beyond the geographic confines of a film venue, suturing the spectator through the lived moments-the act of touch-inhabiting the screen.

The concept of haptics also offers Anna Jackman fertile ground to discuss 3-D cinema and its close relations to tactility and "tactile images." The commercial success of 3-D films intersects with a marketing strategy that promises film viewers an "immersive" cinematic experience capitalizing on the mimetic engineering of the perceptually natural. This appropriation of naturalism has continued to grow and develop as an industry to implicate the audience with a much heightened and highly sensory experience through augmented reality that involves interaction with a synthetic environment. Similar to the audio-guided tours, the development of 3-D, and now 4-D and 5-D cinematic experiences shows the role of technology in creating and producing even more convincing versions of environments through these highly mediated encounters.

If the future of cinema will be determined by technological wizardry, films can also show how technology reconfigures social relations, or in the case of Alex Rivera's film Sleep Dealer, hyperreal labor and border violence. In their contribution to this issue, Altha Cravey, Joseph Palis, and Gabriela Valdivia argue that in this film, the future can be glimpsed through the examination of sleep dealers-or maquiladoras - and cyborg laborers. In this dissection and analysis of Rivera's Spanish-language science fiction film, the future is collectively narrated as a critique of the present. Drawing from activist literature of labor migration, discursive violence, and critical future geographies, the authors devote most of the discussion on the location where the economic geographies of the Global South contest capitalist geopolitics.

Similar to Clarke's deployment of the myth, Christopher Lukinbeal and Laura Sharp's article engages on a different myth as well as the use of media in the active practice of myth-making - that of Joe Arpaio, better known by his moniker "America's Toughest Sheriff." Although Arpaio's self-constructed myth-making has much to do with the strategic and canny use of media that may approximate the folkloric legend of an Oedipus or a Percival, his own rise to right-wing power and prominence is nevertheless reified in the seemingly cinematic landscape of Maricopa County. This Arizona landscape serves as an authentication of the Old West in American lore that populate the Western film genre. Arpaio validates his own often-cruel performances against people not aligned to his nationalistic ideal through the mobilization of his “America's Toughest Sheriff" identity in media. Playing on the tropes of a gate-keeping frontiersman and vigilante, he has been successful in enlisting the help of the local news media to bolster that image.

With an eye toward history, Steven Driever and Nazgol Bagheri show how mass media through radio and newspapers also contributed in bringing attention to a new modality in education in the 1930s through the deployment of experienced travel writers to drum 
up interest in the world and promote peace. Their article centers on two travel writers sponsored by World Letters in 1932 whose epistolary accounts of the world they visited and traveled serve as a gateway in opening a new era in geographic education. Lithographed letters were sent to subscribers as a way to vicariously experience the world through the sympathetic accounts of other cultures. While the initiative of World Letters may be a product of its time, Driever and Bagheri nevertheless argued that the program accomplished its mission, using media to bring "geography into the classroom in a most personal way."

Finally, if the skill and enthusiasm of travel writers can make people pay attention to pre-Second World War global affairs, Jason Dittmer's deconstruction of two games-Model United Nations and Statecraftreveals new ways of seeing beyond the utopian space that mimic the world of geopolitics and international relations. Differently-calibrated spatialities emerge that implicate games as "assemblages with agency," and the recuperation of a new understanding of play that "cultivate new techniques for manipulating our bodies and subjectivities to produce new geopolitical futures."

In the end, we hope that the papers in this special issue offer a wide variety of provocations on different forms of media: by privileging new and particular understandings through analysis and reinvestigations of media's content and form, of the text and political economies, and their possible trajectories and futures.

\section{References}

Bady, A. (2014). Saving Africa, yet again, with a song. Al Jazeera America. http://america.aljazeera.com/opinions/ 2014/11/band-aid-30-bob-geldoffebolaafrica.html. Accessed May 13, 2015.

Baize, S., Pannetier, D., Oestereich, L., Rieger, T., Koivogui, L., Magassouba, N., et al. (2014). Emergence of Zaire Ebola virus disease in Guinea. New England Journal of Medicine, 371(15), 1418-1425.

Boehlert, E. (2014). The Medias Ebola coverage: The more you watch, the less you know? Media Matters For America. http://mediamatters.org/blog/2014/10/15/ebola-coveragethe-more-you-watch-the-less-you/201161. Accessed May 13, 2015.

Canadian Broadcasting Corporation. (1960). Marshall McLuhan's Theory of the global village. http://www.cbc. ca/archives/entry/marshall-mcluhan-the-global-village. Accessed May 13, 2015.

Daheley, T. \& Crookes, D. (2014) Bob Geldof: I don't car about criticism of Band Aid 30. BBC Newsbeat. http://www.bbc. co.uk/newsbeat/article/30374106/bob-geldof-i-dont-careabout-criticism-of-band-aid-30. Accessed May 13, 2015.

Debord, G. (1983). The Society of the Spectacle. Detroit: Red and Black.

Diane Rehm Show. (2014). Friday news roundup-domestic. American University Radio. http://thedianerehmshow.org/ shows/2014-10-17/friday-news-roundup-domestic. Accessed May 13, 2015.

Farmer, P. (2014). Diary. London Review of Books, 36(20), 38-39.

Ferris, S. (2014). Dems call for Ebola flight ban. The Hill. http:// thehill.com/policy/healthcare/220317-dems-call-for-obamato-ban-flights-from-ebola-countries. Accessed May 13, 2015.

Hiebert, P. (2014). The medium is the message, 50 years later. Pacific Standard. http://www.psmag.com/nature-andtechnology/medium-message-50-years-later-91552. Accessed May 13, 2015.

Jaschik, S. (2014). Rejecting all Nigerians? Inside Higher Ed. https://www.insidehighered.com/news/2014/10/15/collegetexas-told-nigerians-they-were-rejected-coming-country-ebola. Accessed May 13, 2015.

MacDonald, M. (2006). Empire and communication: the media wars of Marshall McLuhan. Media, Culture and Society, 28(4), 505-520.

McLuhan, M. (1964). Understanding media: The extension of man. New York: McGraw-Hill.

Meltzer, M. I., Atkins, C. Y., Santibanez, S., Knust, B., Petersen, B. W., Ervin, E. D., et al. (2014). Estimating the future number of cases in the Ebola Epidemic-Liberia and Sierra Leone, 2014-2015. Centers for Disease Control and Prevention Morbidity and Mortality Weekly Report, 63(03), 1-14.

Nelson, S. (2014). Congressman: Close border to Ebola Countries. U.S News \& World Report. http://www.usnews.com/ news/articles/2014/07/30/congressman-close-border-to-ebolacountries. Accessed May 13, 2015.

Olmstead, K., Jurkowitz, M., Mitchell, A., Edna, J. (2013). How American get TV news at home. Pew Research Center Journalism \& Media. http://www.journalism.org/2013/ 10/11/how-americans-get-tv-news-at-home/\#fn-38017-1. Accessed May 13, 2015.

Parker, B. (2014). Band Aid 30: Leave Bob Geldof's Christmas Anthem alone-How much have you raised for Ebola? The Independent. http://www.independent.co.uk/voices/ comment/band-aid-30-leave-bob-geldofs-christmas-anthemalone-how-much-have-you-raised-for-ebola-9872429.html. Accessed May 13, 2015.

Sandmeyer, E. (2014). CNN turns to outbreak fiction writer for Ebola coverage. Media Matters for America. http:// mediamatters.org/blog/2014/10/10/cnn-turns-to-outbreakfiction-writer-for-ebola/201113. Accessed May 13, 2015.

Santora, M. (2014). First patient quarantined under strict new policy tests Negative for Ebola. The New York Times. http://www.nytimes.com/2014/10/25/nyregion/new-yorkebola-case-craig-spencer.html?_r=3. Accessed May 13, 2015. 
Sen, A. (1999). Development as freedom. Oxford: Oxford University Press.

Suddath, C. (2014). This viral video raised $\$ 1.5$ million for Ebola, but who's getting the money? Bloomberg Business. http://www.bloomberg.com/bw/articles/2014-11-24/whois-band-aid-30-raising-money-for. Accessed May 13, 2015.

Szabo, L. (2014). Voices: Even germaphobes don't need to fear Ebola. USA Today. http://www.usatoday.com/story/news/ nation/2014/10/02/ebola-risks-in-perspective/16589979. Accessed May 13, 2015.
Taylor, A. (2014). Listen: The Ebola song that isn't 'do they know it's Christmas?'. The Washington Post. http://www.washing tonpost.com/blogs/worldviews/wp/2014/11/17/listen-theebola-song-that-isnt-do-they-know-its-christmas. Accessed May 13, 2015.

Watts, M. (1983). Silent violence: Food, famine and peasantry in Northern Nigeria. Berkeley: University of California Press.

World Health Organization. (2015). Ebola data and statistics. http://apps.who.int/gho/data/node.ebola-sitrep.ebolasummary?lang=en. Accessed May 13, 2015. 